\section{References}

1. H. J. Grabke: Proceed. 8th Int. Congr. on Metallic Corrosion 1981, DECHEMA, Frankfurt/Main 1981, Vol. III p. 2143-2156.

2. H. J. Grabke, U. Gravenhorst, W. Steinkusch: Werkst. Korros. 27 (1976) 291

3. A. Schnaas, H. J. Grabke: Oxid. Met. 12 (1978) 387.

4. A. Schnaas, H. J. Grabke: Werkst. Korros. 29 (1978) 635

5. 'H. Meurer, H. Schmalzried: Arch. Eisenhüttenwes. 42 (1971) 87.

6. I. Wolf, H. J. Grabke: publication in preparation.

7. J. Hemptenmacher, H. J. Grabke: Werkst. Korros. 34 (1983) 333.

8. O. Demel: Radex-Rundschau 2 (1977) 201.

9. K. Ledjeff, A. Rahmel, M. Schorr: Werkst. Korros. 30 (1979) 767, $31(1980) 83$

10. G. P. Baxter, J. E. Lansing: J. Amer. Chem. Soc. 42 (1920) 419.

11. H. J. Goldschmidt: J.I.S.I. 160 (1948) 345, 170 (1952) 189.

12. K. Kuo: Acta Met. 1 (1953) 301

13. K. Bongartz, D. F. Lupton, H. Schuster: Metallurg. Trans. $11 A$ (1980) 1883.

14. J. Peters, H. J. Grabke: in preparation.

15. J. Stringer: Corr. Sci. 10 (1970) 513-543
16. F. A. Golightly, G. C. Wood, F. H. Stott: Oxid. Met. 14 (1980) 217, 10 (1976) 163.

17. Y. Oishi, W. D. Kingery: J. Chem. Phys. 33 (1960) 480-486.

18. H. A. Wang, F. A. Kröger: J. Amer. Ceram. Soc. 63 (1980) 613-619.

19. K. Kitazawa, R. L. Coble: J. Amer. Ceram. Soc., 57 (1974) 250-253.

20. A. E. Paladino, R. L. Coble: J. Amer. Ceram. Soc., 46 (1963) 133-136.

21. R. E. Mistler, R. L. Coble: J. Amer. Ceram. Soc., 54 (1971) $60-61$.

22. A. E. Paladino, W. D. Kingery: J. Chem. Phys., 37 (1962) 957-962.

23. D. J. Reed, D. J. Wuensch: J. Amer. Ceram. Soc., 63 (1980) 88-92.

24. K. Löhberg, W. Schmidt: Arch. Eisenhüttenwes., 11 (1938) 607-614

25. F. R.Morral: J.I.S.I. 130 (1934) 419-428.

(Received: 09. 06. 1983)

W 2290

\title{
On the influence of cold work on the oxidation of some stainless steels
}

\author{
Einfluß der Kaltverformung auf die Oxidation einiger nichtrostender Stähle
}

\author{
J. C. Langevoort, T. Fransen and P. J. Gellings*
}

Oxidation experiments, performed by means of light interference microscopy, give information of the initial oxidation on a microscopic scale. A thin oxide layer on the substrate gives rise to an interference colour, which is directly correlated to the thickness of this layer. It is shown that not all stainless steels react in the same way to the same pretreatments. The oxidation behaviour of drawn AISI 304 and AISI 321 is completely different from that of Incoloy $800 \mathrm{H}$, while the undeformed and recrystallized samples all show the same oxidation behaviour. It is suggested that this behaviour of AISI 304 and AISI 321 , is caused by the formation of $\alpha^{\prime}$ martensite in the deformed austenitic matrix.
Oxidationsversuche in Verbindung mit optischer Interferenzmikroskopie liefern Aussagen über die Anfangsstadien der Oxidation im Mikrobereich. Die auf dem Substrat entstehende dünne Oxidschicht führt zum Auftreten einer Interferenzfarbe, die direkt mit der Dicke dieser Schicht korrelierbar ist. Es wird gezeigt, daß das Verhalten der nichtrostenden Stähle auch bei gleicher Vorbehandlung verschieden ist. So ist das Oxidationsverhalten von gezogenem Stahl AISI 304 und 321 vollkommen anders als das von Incoloy $800 \mathrm{H}$, während unverformte und rekristallisierte Proben sich gleich verhalten. Dieses Ver halten der Stähle 304 und 321 ist wahrscheinlich der Bildung von $\alpha^{\prime}$ Martensit in der verformten austenitischen Matrix zuzuschreiben.

\section{Introduction}

In the literature it is found that cold work may have a positive effect on the corrosion resistance [1]. However, not only positive effects have been observed. Cigada et al. [2] showed that the deformation temperature is of great impor-

\footnotetext{
* Drs. J. C. Langevoort, Dr. T. Fransen, Prof. Dr. P. J. Gellings, Twente University of Technology, Dept. of Chemical Technology, P. O. Box 217, NL-7500 AE Enschede.
}

tance. AISI 304 deformed at liquid nitrogen temperature showed a decrease in resistance to SCC (Stress Corrosion Cracking). Allan and Dean [3] report that surface treatments may produce one or more zones of differing structure. In the temperature range of $900-1000 \mathrm{~K}$ they found that the corrosion resistance in $\mathrm{CO}_{2}$ and $\mathrm{He}$ atmosphere was increased. Leistikow [4] reports a beneficial effect of cold work on the corrosion of Incoloy 800 to superheated steam at temperatures below $1073 \mathrm{~K}$, but a negative effect at temperatures above $1173 \mathrm{~K}$. 
There are many theories about the effects mentioned. Cigada et al. [2] correlate the reduced stress corrosion resistance to an increase in the level of internal microstresses. These microstresses are generated by a reciprocal reordering of the $\alpha^{\prime}$ and $\varepsilon$ structural phases. In order to obtain more information about the change in corrosion resistance due to cold work, the investigations reported here, were concentrated on AISI 304 and Incoloy $800 \mathrm{H}$. Both steels have an austenitic structure. It is known that in AISI 304 cold work may produce some $\alpha^{\prime}$ and $\varepsilon$ martensite in its austenite matrix, while Incoloy $800 \mathrm{H}$, which is one of the more stable austenites, does not show this behaviour [5]. AISI 321, a titanium stabilized 18/8 stainless steel was also used. The titanium is added to prevent sensitization i.e. the formation of grain boundary carbides, at temperatures around $900 \mathrm{~K}$.

\section{Experimental}

Table 1 gives the composition of the three stainless steels used in this investigation. Prior to oxidation all specimens were treated as follows:

i) heat treatment at $1370 \mathrm{~K}$ for $1 \mathrm{hr}$,

ii) heat treatment at $1220 \mathrm{~K}$ for $1 \mathrm{hr}$.

Table 1. Chemical composition of the steels investigated

Tabelle 1. Chemische Zusammensetzung der untersuchten Stähle

\begin{tabular}{lllllllll}
\hline & $\mathrm{Cr}$ & $\mathrm{Ni}$ & $\mathrm{Ti}$ & $\mathrm{Mn}$ & $\mathrm{Si}$ & $\mathrm{C}$ & $\mathrm{S}$ & $\mathrm{Fe}$ \\
\hline AISI 304 & 17.39 & 8.88 & - & 1.27 & 0.70 & 0.044 & 0.017 & bal. \\
AISI 321 & 17.45 & 10.13 & 0.40 & 1.55 & 0.52 & 0.048 & 0.003 & bal. \\
Incoloy 800 H & 19.90 & 31.70 & 0.42 & 0.72 & 0.49 & 0.080 & 0.080 & bal.
\end{tabular}

The last treatment was strictly necessary only for the stainless steels with titanium, to form titanium carbides instead of chromium carbides. For reasons of uniformity AISI 304 was also given this treatment. After both treatments the specimens were water quenched. The oxidation tests were performed with deformed and undeformed samples. All samples were ground with 220 to 800 grit SiC emery paper with water cooling and polished with $6 \mu \mathrm{m}$ diamond paste and $0.05 \mu \mathrm{m}$ alumina powder. The specimens were then cleaned ultrasonically in ethanol, electropolished (electrolyte A 2) and finally cleaned ultrasonically again. Deformed samples were obtained by drawing bars in a tensile testing machine in air and without cooling. The oxidation tests were performed in a Vacutherm vacuum chamber mounted on a Melabor microscope (Reichert) [6]. All photographs were made with dia-positive film in order to minimize errors in colour reproduction. The oxidation experiments were performed in a $\mathrm{N}_{2}$ atmosphere with $945 \mathrm{ppm} \mathrm{O}_{2}$ and $25 \mathrm{ppm} \mathrm{CO}_{2}$. No $\mathrm{CO}$ was detected with a gas chromatograph (Varian). The gas composition was chosen because with this low oxygen content the oxidation was slow enough to be photographed at the temperatures used (770-970 K).

\section{Theory}

It is well known that with interference microscopy the colour changes during oxidation can be used to determine the thickness of the oxide layer (complementary interference colours) [7-9]. These colour changes occur in the order straw, reddish-yellow, red-brown, purple, violet, blue, silvery-green, yellow-green, yellow, straw, yellow-brown, dark brown. From silvery-green, colours are of second order. The corresponding thickness of the first order colours is $460,520,580,630,680$ and $720 \AA$ (measured for FeO oxide film [7]). The relation between colour and thickness is given by

$$
\Delta=2 \mathrm{nd} \cos \varnothing+\Delta^{\prime}
$$

where $\Delta$ is optical path difference, $\mathrm{d}$ the thickness, $\mathrm{n}$ the refractive index and $\varnothing$ the angle between refracted light and the normal to the surface plane. $\Delta^{\prime}$ is the path difference due to a phase shift at the oxide/metal interface. Unknown factors are anisotropy, inhomogeneity of the oxide and the phase shift at the oxide metal interface.

\section{Results}

Figures 1-3, 4-6 show the course of oxidation of deformed AISI 304 and Incoloy $800 \mathrm{H}$, respectively. All oxidation experiments followed a parabolic law. It is difficult to make an exact comparison between the results:

i) the determination of the time of the beginning of the experiment is not very accurate

ii) due to the very gradual ch inge in colour the error in determining the wave length of a colour at a certain time can be rather large.

The beginning of an experiment is defined as the time where the temperature of the sample has reached its final value. It took about 3 minutes to heat the sample from room temperature to $720 \mathrm{~K}$. In Figures 1-3 different colours are visible on different areas on the sample. There are small crystallites where the initial oxidation is very fast but then reaches a steady state condition, and other crystallites where the initial oxidation is much slower but where the steady state will be reached. So after a while these slowly oxidizing crystallites catch up on the initially fast oxidizing crystallites. This behaviour has been observed both on AISI 304 and on AISI 321. Incoloy $800 \mathrm{H}$, however, does not show this effect. Undeformed AISI 304, AISI 321 and Incoloy $800 \mathrm{H}$ oxidize in the same way: initially some crystallites oxidize faster than others,

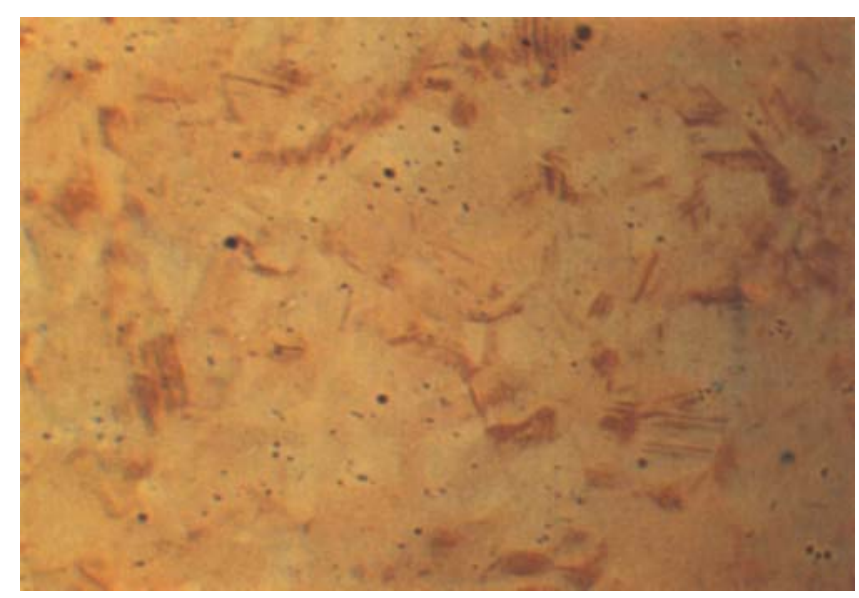

Fig. 1. 9,4\% deformed AISI 304. Oxidation time $1 \mathrm{~min}$; temperature $770 \mathrm{~K}, \alpha^{\prime}$ martensite areas reddish brown, austenite areas straw Abb. 1. $\mathrm{Zu} \mathrm{9,4 \%} \mathrm{deformierter} \mathrm{Stahl} \mathrm{AISI} \mathrm{304.} \mathrm{Oxidationszeit} 1 \mathrm{~min}$; $\mathrm{T}=770 \mathrm{~K}, \alpha^{\prime}$-Martensit-Teile rost-braun, Austenit-Teile stroh-gelb $(0,1 \mathrm{~mm})$ 


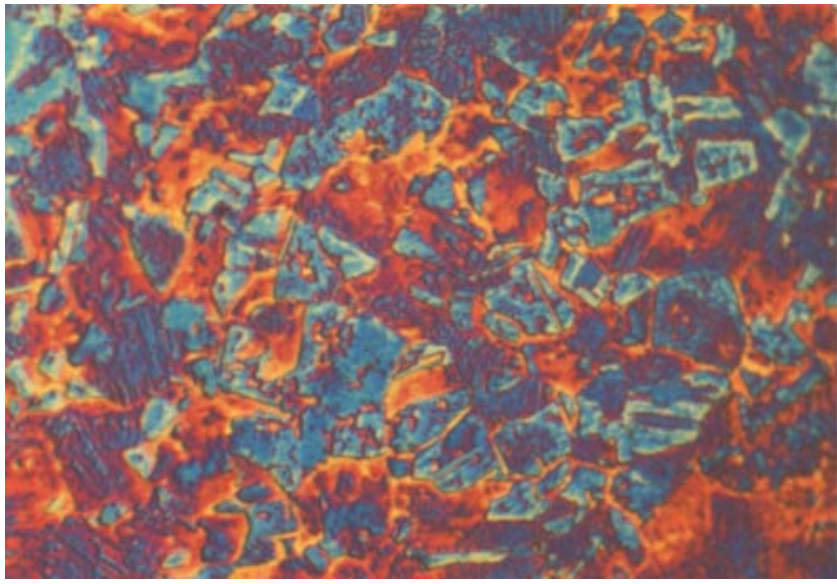

Fig. 2. As Fig. 1, oxidation time 8 min. $\alpha^{\prime}$ martensite area dark blue; austenite areas light blue

Abb. 2. Wie Abb. 1, Oxidationszeit 8 min. $\alpha^{\prime}$-Martensit-Teile dunkelblau und Austenit-Teile hellblau

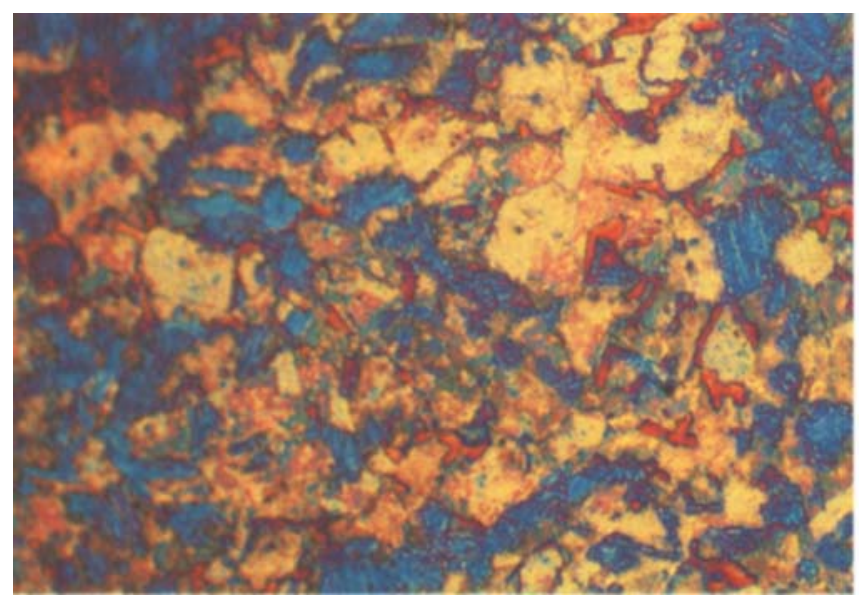

Fig. 3. As Fig. 1, oxidation time 60 min. $\alpha^{\prime}$ martensite areas still dark blue; austenite areas yellow brown

Abb. 3. Wie Fig. 1, Oxidationszeit 60 min. $\alpha^{\prime}$-Martensit-Teile dunkelblau und Austenit-Teile gelbbraun

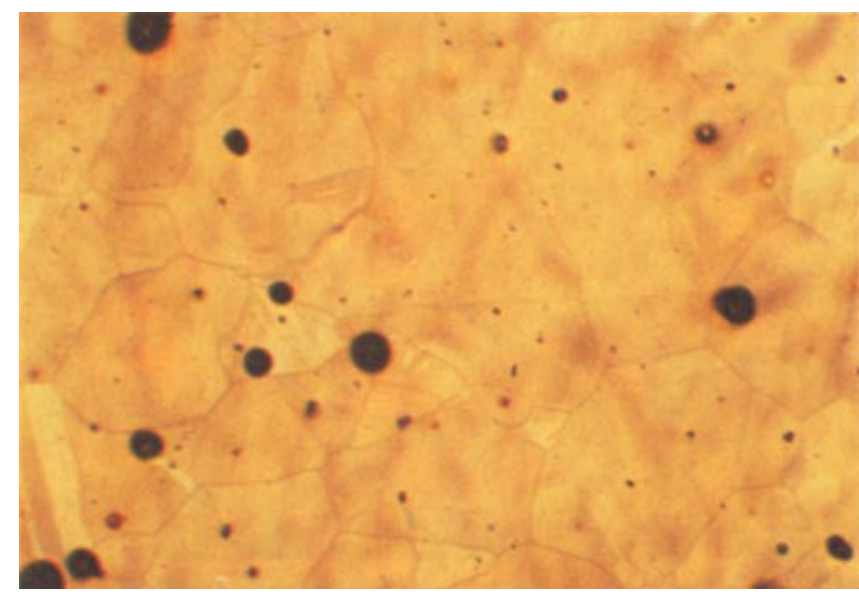

Fig. 4. Incoloy $800 \mathrm{H}, 10 \%$ elongation, oxidation time $1 \mathrm{~min}, \mathrm{~T}=940$ $\mathrm{K}$

Abb. 4. $\mathrm{Zu} 10 \%$ deformierter Stahl Incoloy $800 \mathrm{H}$, Oxidationszeit 1 $\min . ; \mathrm{T}=940 \mathrm{~K}(\underline{0,1 \mathrm{~mm}})$

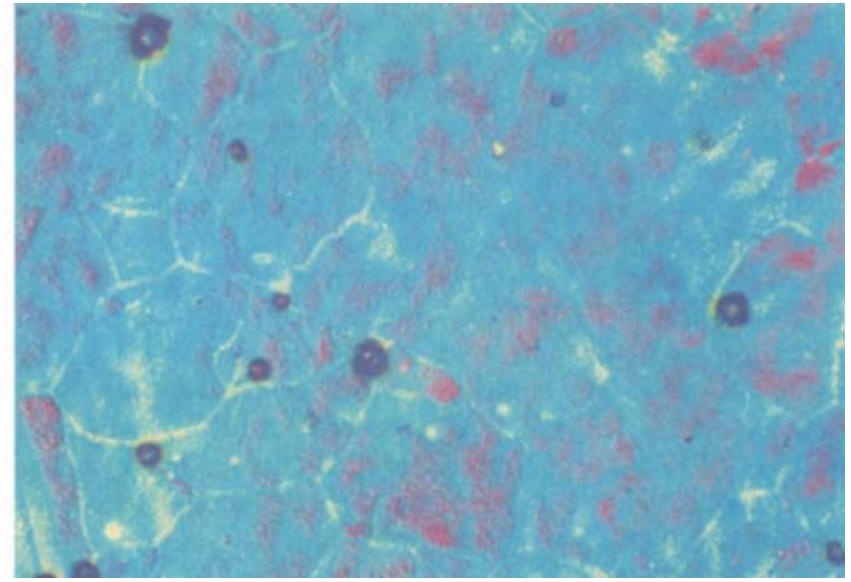

Fig. 5. As Fig. 4, oxidation time $7 \mathrm{~min}$ Abb. 5. Wie Abb. 4, Oxidationszeit 7 min

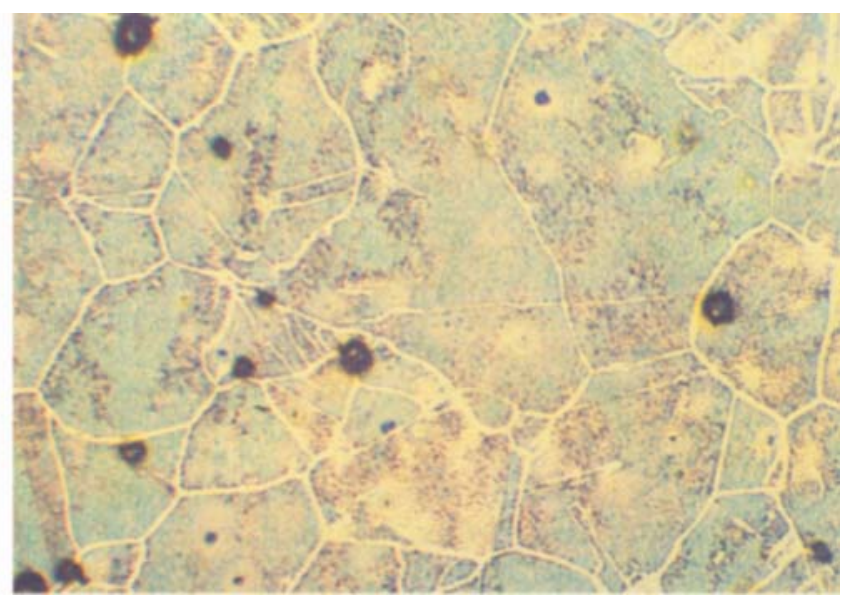

Fig. 6. As Fig. 4, oxidation time $34 \mathrm{~min}$

Abb. 6. Wie Abb. 4, Oxidationszeit $34 \mathrm{~min}$

probably due to difference in crystal orientation. But after a while the oxidation rates of all crystallites are equal, and the difference in colour between the crystallites remains constant over the whole oxidation experiment.

The only difference between AISI 304 and AISI 321 is the faster oxidation of AISI 304. As might be expected sensitization did not occur with AISI 321. However, AISI 304 did not show sensitization either, because of the exposures used, and its relatively low carbon content $(0.044 \%)$. This is in agreement with exposures used in literature $[12,13]$. Figures $4-6$ show the oxidation behaviour of Incoloy $800 \mathrm{H}$ with an elongation of $10 \%$. The different crystallites can easily be seen. The oxidation rate of all crystallites is equal for all orientations. Figure 7 shows a normal image of two planes of AISI 321. Figure 8 shows the same area but now with a multiple interference accessory (Nomarski [10-11]). The displacement of the interference line is a measure of the height difference of the two planes. The height difference shown here is about 44.6 $\mathrm{nm}$. This is in good agreement with the value of $46.0 \mathrm{~nm}$ for $\mathrm{FeO}$ calculated from the data reported by Kubaschewski [7]. 


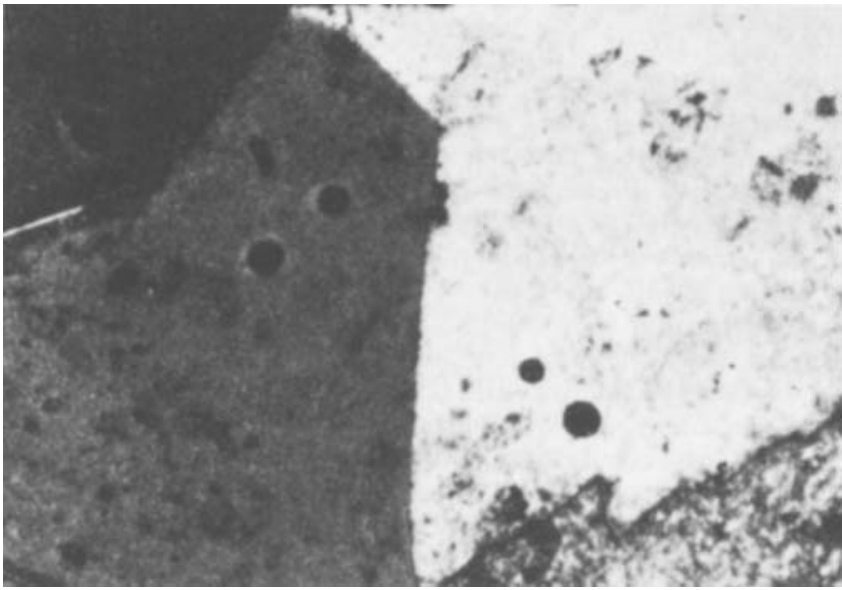

Fig. 7. Undeformed AISI 321; oxidation time $2 \mathrm{hrs,} \mathrm{T}=940 \mathrm{~K}$; left dark blue and right yellow

Abb. 7. Undeformierter Stahl AISI 321; Oxidationszeit 2 Std., $T=$ $940 \mathrm{~K}$; linke Seite dunkelblau und rechte Seite gelb (0,1 mm

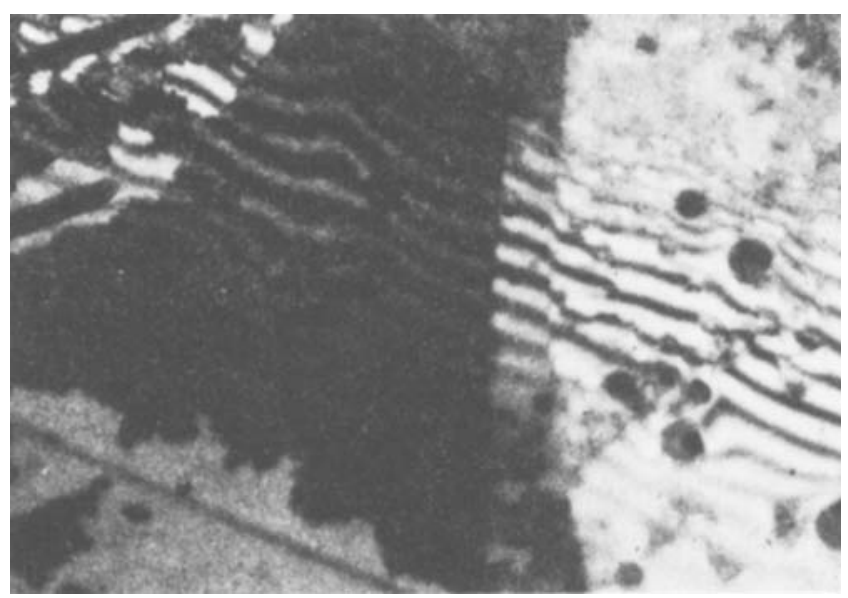

Fig. 8. As Fig. 7, with Nomarski interference accessory

Abb. 8. Wie Abb. 7, mit Nomarski Interferenzzubehör

Although it is expected that $\mathrm{Cr}_{2} \mathrm{O}_{3}$ and $\mathrm{Fe}_{2} \mathrm{O}_{3}$ are the main constituencies in the oxide, the refractive index will not be very much different for these thin layers

(FeO: $\mathrm{n}=2,32 ; \mathrm{Fe}_{2} \mathrm{O}_{3}: \mathrm{n}=2,42$ and $\mathrm{Cr}_{2} \mathrm{O}_{3}: \mathrm{n}=2,5$ ).

The relationship between height difference and displacement is

$\mathrm{d}=\frac{\lambda}{2 \mathrm{a} / \mathrm{b}}$

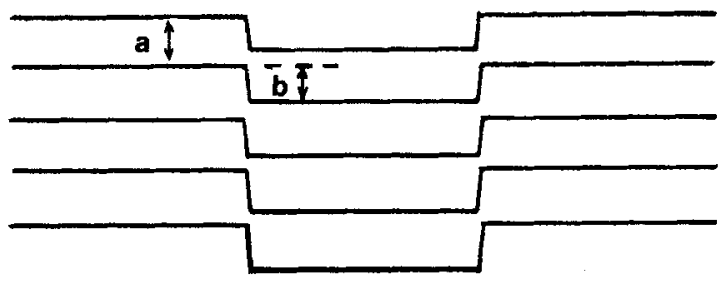

Fig. 9. Interference lines over a small height difference

Abb. 9. Interferenzlinienverschiebung durch eine Höhendifferenz where $d$ is the height difference, $\lambda$ the wave length, a the distance between two interference lines and $b$ the distance between the interference lines and the displaced ones (Fig. 9). However, it was not possible to obtain the exact thickness of an oxide layer at a certain time. The differences in thickness between adjacent oxides were too small to make these visible with a Nomarski or other accessory. Also the lines are broadened too much, due to the roughness of the oxide, making it impossible to determine the height differences outside the experimental error.

\section{Discussion}

i) Stainless steel AISI 304 and AISI 321 show the same oxidation behaviour with a decreasing corrosion resistance with increasing deformation. Since the samples were drawn below the $\mathbf{M}_{d}$ temperature (the temperature above which, even after severe cold work, no martensite is formed) of $340 \mathrm{~K}$, martensite was formed within the austenitic matrix. Martensite being body centered cubic will have a higher rate of diffusion for chromium [14]. On the martensite sites the oxidation is initially fast, while after a short time the oxidation becomes very slow (Figs. 1-3), indicating that a good protective oxide has been formed. However, it will be difficult to separate the effects of cold work (increased dislocation density along slip planes and formation of martensite platelets). On the austenite matrix, the initial oxidation is much slower, but as the oxidation proceeds, these areas overtake the martensite areas and at the end of an oxidation experiment the thickness of the oxide layer is larger on the austenite than on the martensite areas.

ii) Incoloy $800 \mathrm{H}$ shows another oxidation behaviour (Figures 4-6). In contrast with Leistikow [4], who reports a beneficial effect of cold work on the oxidation resistance at temperatures below $1173 \mathrm{~K}$, Incoloy $800 \mathrm{H}$ was observed to oxidize faster when deformation was applied. Unlike AISI 304 and AISI 321, Incoloy $800 \mathrm{H}$ showed grain boundary oxidation in all cases in this investigation (presumably due to a slight etching of the unoxidized surface). Unlike AISI 304 and AISI 321, all crystallites of Incoloy $800 \mathrm{H}$ oxidized fairly homogeneously and there are no areas within the crystallites where the oxidation rate differs much from the rest of the crystallites. Leistikow [4] suggested that grain growth plays a major role in the disadvantageous effect of cold work on the oxidation resistance above $1100 \mathrm{~K}$. However, at the temperatures used in this investigation no grain growth will occur and no beneficial effect of cold work has been seen (even at higher temperatures 1000-1400 K [15])

This indicates that in Incoloy $800 \mathrm{H}$ the diffusivity of ignoble alloy components such as $\mathrm{Cr}$ and $\mathrm{Si}$ along easy diffusion paths like grain boundaries does not play the most important role in this behaviour. Perhaps the defect structures of the metal and its oxide are of more importance. Due to cold work the concentration of defects in the metal is increased. In the oxide layer this may result in an increased amount of defect too, creating easy diffusion paths in the oxide layer itself and as a consequence a faster oxidation. Therefore the oxidation resistance of Incoloy $800 \mathrm{H}$ decreases with increasing deformation.

Even at high temperatures $(1000-1400 \mathrm{~K})$ the formation of $\alpha^{\prime}$ martensite has a positive influence on the oxidation resistance [15] of AISI 304 and AISI 321 which show an increasing oxidation resistance with increasing deformation at these temperatures, while the oxidation rate of Incoloy $800 \mathrm{H}$ increases with increasing deformation. 
In all cases no investigation has been done into the composition of the oxide layer. This is merely due to the thickness of the layer itself, $80 \mathrm{~nm}$ being below the detection limit of X-ray diffraction, X-ray fluorescence or Edax. In future ellipsometry and Auger electron spectroscopy (AES) will be used in order to follow the oxidation from monolayer to about $10 \mathrm{~nm}$. With AES it will be possible to determine the composition of these very thin layers (detection limit AES is about 1-2 nm).

\section{Conclusions}

Interference microscopy can be a useful tool in the study of oxidation of metals and alloys. Due to the formation of an $\alpha^{\prime}$ martensite phase, deformed AISI 304 and AISI 321 have a better oxidation resistance than undeformed specimens. This indicates that the second phase creates easy diffusion paths for chromium in the metal, which results in a better protective oxide. The increased oxidation of Incoloy $800 \mathrm{H}$ is a result of the deformation causing the creation of more defects in the oxide layer. These defects, homogeneously distributed throughout the metal crystallites, lead to an increased defect concentration in the oxide, resulting in a less protective oxide. As a result, Incoloy $800 \mathrm{H}$ oxidizes faster with increasing deformation.

\section{Acknowledgement}

We thank M. A. de Jongh for his experimental contributions.

\section{References}

1. Nippon Kokan Comp., Techn. Bull. TD 49-008 (1974).

2. A. Cigada et al., Corr. Sci. 22 (1982) 559.

3. S. J. Allan, M. J. Dean in "Behaviour of high temperature alloys in agressive environments", ed. I. Kirmann et al., Proc. Int. Conf. Petten (1979), p. 319, The Metals Society, London.

4. S. Leistikow in "Behaviour of high temperature alloys in agressive environments", ed. I. Kirmann et al., Proc. Int. Conf. Petten (1979), p. 197.

5. G. J. Novak: Handbook of Stainless Steels, ed. D. Pecker and $I$. M. Bernstein, McGraw-Hill (1977).

6. P. J. Gellings, M. A. de Jongh: Corr. Sci. 7 (1967) 413.

7. O. Kubaschweski, B. E. Hopkins: "Oxidation of metals and alloys", Butterworths, London (1962).

8. U. R. Evans: "The corrosion and oxidation of metals", Arnold, London (1960).

9. A. T. Gwathmey, F. W. Youngh: Rev. de Metallurgie XLVIII 6 (1951).

10. G. Nomarski, A. R. Weill: Rev. de Metallurgie LII 2 (1955).

11. S. Tolanski: Multiple beam interferometry of surfaces and films, Oxford (1948).

12. A. J. Sedriks: Corrosion of stainless steels, Wiley, NY (1979).

13. H. H. Uhlig: Corrosion and corrosion control, Wiley, NY (1963).

14. S. Pednekar, S. Smialowska: Corrosion 10 (1980) 565-577.

15. J. Langevoort, T. Fransen, P. J. Gellings: to be published. 